\title{
BMP system expression in GCs from polycystic ovary syndrome women and the in vitro effects of BMP4, BMP6, and BMP7 on GC steroidogenesis
}

\author{
Mohamad Khalaf ${ }^{1,2}$, Julia Morera ${ }^{1,2,3}$, Antoine Bourret ${ }^{1,2}$, Yves Reznik $^{1,2,3}$, Christine Denoual ${ }^{4}$, \\ Michel Herlicoviez ${ }^{4}$, Hervé Mittre ${ }^{1,2,5}$ and Annie Benhaim ${ }^{1,2,4}$ \\ ${ }^{1}$ Laboratoire, EA 2608, Université de Caen-Basse Normandie, F-14032 Caen Cedex, France, ${ }^{2}$ INRA, USC 2006, F-14032 Caen Cedex, France, \\ ${ }^{3} \mathrm{CHU}$ de Caen, Service d'Endocrinologie, F-14033 Caen Cedex, France, ${ }^{4} \mathrm{CHU}$ de Caen, Service de Gynécologie Obstétrique, Laboratoire de Fécondation \\ In Vitro, F-14033 Caen Cedex, France and ${ }^{5}$ CHU de Caen, Laboratoire de Génétique Moléculaire, F-14033 Caen Cedex, France
}

(Correspondence should be addressed to A Benhaim; Email: benhaim-a@chu-caen.fr)

\begin{abstract}
Background: The bone morphogenetic proteins (BMPs) are growth factors involved in the folliculogenesis. Alteration in their expression may compromise the reproductive process in disease such as the polycystic ovary syndrome (PCOS). This study investigated the expression and role of granulosa cell (GC) BMP from normal cycling and PCOS women.

Methods and results: This prospective study was performed in GCs obtained from 14 patients undergoing IVF: i) six women with normal ovulatory cycles and tubal or male infertility and ii) eight women with PCOS. BMP2, BMP4, BMP5, BMP6, BMP7, and BMP8A and their receptors BMPR1A, $B M P R 1 B$, and BMPR2 were identified by RT-PCR in GCs from normally cycling and PCOS women. BMP4, BMP6, and BMP7 expressions were confirmed by immunohistochemistry. Quantitative transcript analysis showed the predominant expression of BMP6. In GCs from PCOS women, an overexpression of BMP6 $(P<0.01)$ and BMPR1A mRNA $(P<0.05)$ was observed. GC culture experiments demonstrated that basal estradiol $\left(\mathrm{E}_{2}\right)$ production was threefold higher but FSH-induced $\mathrm{E}_{2}$ increment was twofold lower in PCOS compared with controls. In PCOS, BMP6 and BMP7 exerted a stimulatory effect on basal $\mathrm{E}_{2}$ production while BMP4 and BMP6 inhibited FSH-induced $\mathrm{E}_{2}$ production. FSH receptor and aromatase expression were not different between both groups.

Conclusion: The BMP system is expressed in human GCs from normal cycling and PCOS women. The BMP may be involved in reproductive abnormalities found in PCOS.
\end{abstract}

European Journal of Endocrinology 168 437-444

\section{Introduction}

Polycystic ovary syndrome (PCOS) is a common endocrine disease affecting $6-10 \%$ of premenopausal women of childbearing age. This clinically heterogeneous disorder appears as the main cause of female infertility (1). The pathophysiology of this ovulatory disorder affecting folliculogenesis is still puzzling. There is evidence for a primary ovarian dysfunction in PCOS reflected by the dramatic increase in the number of small growing follicles at the expense of the dominant follicle selection from the increased pool of selectable follicles $(2,3,4)$. Bone morphogenetic proteins (BMPs), which are functionally involved at all stages of folliculogenesis, are multifunctional growth factors belonging to the transforming growth factor $\beta$ (TGF $\beta$ ) superfamily. Evidence from studies on rodents indicate an autocrine/paracrine role for granulosa-derived BMP6, theca-derived BMP4 and BMP7, and a paracrine role of oocyte-derived growth differentiation factor 9 (GDF9), BMP15, and BMP6 on granulosa cell (GC) proliferation and on FSH-dependent follicle functions. BMP actions are mediated by their receptors (BMPRs) that share a different degree of affinity for their ligands (5). Unbalanced exposure to BMPs may alter the follicle sensitivity to FSH and thus impair the process of dominant follicle selection. In rodent and mammalian species, GDF9, another member of the BMP family, and BMP15 play a key role on folliculogenesis and female fertility $(6,7,8,9,10)$. Disruption of follicle development and subsequent infertility were demonstrated in sheep sharing a homozygous mutation of BMP15 gene (9). In rodent ovary, BMP7 contributes to primordial follicle activation and also to the primordialto-primary follicle transition (11). Later in the follicle growth process, loss of BMP6 expression should play a key role for the dominant follicle selection (12). BMP contribution to follicle selection is driven by suppressive 
or stimulating effects on FSH action $(11,13,14)$. In contrast to rodent, bovine, and ovine species, the role of BMPs in human folliculogenesis has been poorly investigated. BMP6 and BMP7 were shown to stimulate FSH receptor expression in normal human GCs $(15,16)$. In comparison with healthy ovulatory women, a decrease in GDF9 expression was demonstrated in women with PCOS (10). In light of these data, disturbances at different stages of folliculogenesis may be due to alterations in the expression pattern of BMP genes in PCOS.

In this study, we have investigated the expression pattern of BMPs including BMP4, BMP6, and BMP7 and their receptors BMPR1A, BMPR1B, and BMPR2 in granulosa luteinizing cells from women affected by PCOS, which were compared with healthy ovulatory women. Moreover, the effects of BMPs on estradiol $\left(E_{2}\right)$ production in cultured GCs from normally cycling and PCOS women were studied.

\section{Materials and methods}

\section{Patients}

This prospective study concerned women undergoing IVF, women with anovulatory PCOS $(n=8)$, and women with healthy ovulatory function undergoing IVF for tubal and/or male infertility $(n=6)$. Their age ranged between 20 and 35 years. According to Rotterdam criteria 2003, the diagnosis of PCOS was based on the association of two out of three of the following criteria: i) ovulatory dysfunction, oligomenorrhea, or amenorrhea; ii) more than 12 follicles in the 2-9 mm range in each ovary at ultrasonography and/or an ovarian volume $>10 \mathrm{ml}$; and iii) clinical and/or biological hyperandrogenism. Exclusion criteria for control women were: an age > 35 years; a history of menstrual disturbance, hirsutism, or endometriosis; high prolactin or androgen serum levels; FSH > $>10 \mathrm{IU} / \mathrm{l}$ at day 3 after menstrual bleeding; and PCOS ovarian pattern at ultrasonography.

All patients gave informed consent before their inclusion in the study. This study was approved by the Institutional Review Board of the University Hospital of Caen. This work is supported by Program Hospitlalier de Recherche Clinique (PHRC), France.

\section{Stimulation protocol}

Follicular growth was stimulated by a s.c. injection of recombinant FSH (rFSH; Gonal-F; Merck-Serono) at 150-225 IU/day on the second day of the menses induced by progesterone (Duphaston; Abbott). Follicular growth was monitored by serum $\mathrm{E}_{2}$ level and transvaginal ultrasonography. A GNRH antagonist (Cetrotide; Merck-Serono) was administered i.m. at dose $0.25 \mathrm{mg} /$ day (multiple dose protocol) starting from the day when the dominant follicles reached a mean diameter $14 \mathrm{~mm}$ and/or when peripheral $\mathrm{E}_{2}$ level reached $700 \mathrm{pg} / \mathrm{ml}$ and was repeated until the day of i.m. administration of human chorionic gonadotropin (hCG). hCG (5000 IU i.m.) was administrated when at least three follicles reached a mean diameter of $18 \mathrm{~mm}$. Oocyte retrieval was performed $36 \mathrm{~h}$ later under transvaginal ultrasound guidance.

\section{Isolation of GCs}

After oocyte retrieval, all follicular fluids from each patient were pooled and stored in a tube. Cells were collected by centrifugation for $10 \mathrm{~min}$ at $300 \mathrm{~g}$. The cell pellet was resuspended in $1 \mathrm{ml}$ minimal essential medium (PAN Biotech, Aidenbach, Germany), supplemented with $100 \mathrm{IU} / \mathrm{ml}$ penicillin, $100 \mu \mathrm{g} / \mathrm{ml}$ streptomycin, and $2 \mu \mathrm{g} / \mathrm{ml}$ amphotericin B. The suspension overlayed on $3 \mathrm{ml}$ Ficoll (PAN Biotech) was centrifuged at $600 \boldsymbol{g}$ for $5 \mathrm{~min}$. Granulosa-luteinized cells were aspirated from the interface, washed with medium, and counted on a hemacytometer. One part of the cells was used for culture and the rest were stored at $-80{ }^{\circ} \mathrm{C}$ until mRNA and proteins analysis.

\section{RNA extraction and RT}

Total mRNA was extracted from GCs using the kit Tri Reagent (Sigma-Aldrich). For each sample, RT was performed in a total volume of $40 \mu \mathrm{l}$ with $1 \mu \mathrm{g}$ RNA, $0.2 \mu \mathrm{g}$ oligo-dT as primers in the presence of $\mathrm{dNTP}$ $(500 \mu \mathrm{g} ;$ Promega), RNAsin (20 IU; Promega), and Moloney murine leukemia virus reverse transcriptase (200 IU; Promega) for $1 \mathrm{~h}$ at $42{ }^{\circ} \mathrm{C}$.

\section{RT-PCR analysis}

The cDNA obtained was used to evaluate the BMPs' mRNA profile expression in GCs. Amplification was performed at $94{ }^{\circ} \mathrm{C}$ for $45 \mathrm{~s}$ for denaturing, at $60{ }^{\circ} \mathrm{C}$ for $45 \mathrm{~s}$ for annealing, and at $72{ }^{\circ} \mathrm{C}$ for $1 \mathrm{~min}$ for extinction with 1.5 IU Taq DNA polymerase (Promega) in a buffer containing $200 \mathrm{mmol} / \mathrm{l} \mathrm{dNTP,} 1.5 \mathrm{mmol} / \mathrm{l} \mathrm{MgCl}_{2}$, and 25 pmol of each primer (Eurogentec, Liege, Belgium) in a total volume of $50 \mu \mathrm{l}$. Thirty-three cycles of PCR for FSH receptor and actin were performed. Primers used in supplemental data are summarized in Table 1.

\section{Real-time RT-PCR analysis}

Evaluation of gene expression levels was achieved by real-time quantitative PCR using SYBR Green. Real-time PCR was performed with $3 \mu \mathrm{l}$ appropriate cDNA using GoTaq qPCR Master Mix (Promega) according to the manufacturer's instruction; forward- and reversespecific primers for human BMP4, BMP6, BMP7, BMPR1A, BMPR1B, and BMPR2 (Supplementary Table 1, see section on supplementary data given at the end of this article) in a Stratagene Mx 3005P (Agilent 
Table 1 Clinical parameters in normo-ovulatory controls and patients with PCOS. Values are median with 10th-90th percentiles (in parentheses).

\begin{tabular}{lccc}
\hline & Controls & $\begin{array}{c}\text { PCOS } \\
\text { patients }\end{array}$ & $\boldsymbol{P}$ value \\
\hline$n$ & 6 & 8 & \\
Age (years) & $29.5(26-33)$ & $29.5(23-32)$ & 0.85 \\
$\mathrm{BMl}\left(\mathrm{kg} / \mathrm{m}^{2}\right)$ & $21.7(18-23)$ & $25.4(19-41)$ & 0.1 \\
$\mathrm{rFSH}$ totals (IU) & $1275(1065-3690)$ & $1350(930-1470)$ & 0.57 \\
Number of follicles & $9(4-12)$ & $10(3-19)$ & 0.4 \\
$\quad \begin{array}{c}\text { Number of follicles } \\
\quad<14 \mathrm{~mm}\end{array}$ & $12(1-16)$ & $18(3-30)$ & 0.08 \\
$\quad$ & & & \\
\hline
\end{tabular}

Technologies, Santa Clara, CA, USA). The PCR protocol used an initial denaturing step at $95^{\circ} \mathrm{C}$ for $3 \mathrm{~min}$ followed by 40 cycles at $95^{\circ} \mathrm{C}$ for $15 \mathrm{~s}$ and annealing at $61{ }^{\circ} \mathrm{C}$ for $1 \mathrm{~min}$. Results were analyzed using Mxpro v4.10 Software (Stratagene). Relative gene expression was calculated as a ratio of each target concentration to housekeeping gene actin concentration. The identity of all PCR amplicons was confirmed by sequencing.

\section{Immunohistochemistry}

Cells were mounted and fixed in $4 \%$ paraformaldehyde on slides precoated with polylysine. All the primary antibodies were purchased from Santa Cruz Biotechnology (Santa Cruz, CA, USA) and included exclusively those proven suitable for immunohistochemistry by the manufacturer. The primary antibodies included goat polyclonal antibodies against BMP4, BMP6, BMP7, BMPR1A, BMPR2, and aromatase (Supplementary Table 2, see section on supplementary data given at the end of this article). The secondary antibodies used were coupled with FITC for BMP7 and with Texas red for aromatase. Control staining was performed on adjacent serial sections and consisted in replacing the primary antibody with PBS-BSA 3\%. Slides were mounted with mounting medium with DAPI (Santa Cruz Biotechnology). Images were captured using a confocal microscope (Olympus Fluo View FV 1000).

\section{Primary cell culture}

GCs were cultured in a 24-well plate with $0.5 \mathrm{ml}$ medium (Milieu Essential Minimum de Eagle, Dutcher, Brumath, France) supplemented with SVF at $37^{\circ} \mathrm{C}$ in an atmosphere of $5 \% \mathrm{CO}_{2}$ in air. After 72 -h culture, $10^{-7} \mathrm{M}$ androstenedione, a substrate for P450 aromatase, was added to the media. GCs were cultured in the presence or absence of $500 \mathrm{mUI} / \mathrm{ml} \mathrm{FSH}$ and in the presence or absence of BMP4, BMP6, or BMP7. BMP4, BMP6, and BMP7 were purchased from Sigma-Aldrich Co. Ltd. The dose of BMP used was $50 \mathrm{ng} / \mathrm{ml}$ as described previously in rat GCs (17). After $48 \mathrm{~h}$ of culture, the supernatant of culture media was collected and stored at $-20{ }^{\circ} \mathrm{C}$ until assay for $\mathrm{E}_{2}$.

\section{Assessment of $E_{2}$ production}

The level of $\mathrm{E}_{2}$ was measured in the $10 \mu \mathrm{l}$ culture media by a RIA (P.A.R.I.S antibodies). The within-assay coefficient of variation (CV) was 5\%, the betweenassay CV was $10 \%$, and sensitivity of estrogen assay was $60 \mathrm{pg} / \mathrm{ml}$.

\section{Statistical analysis}

Because values from any parameter were not normally distributed, all comparisons between PCOS and control were performed using the nonparametric MannWhitney $U$ test. Univariate analysis of correlation between expressions of the different parameters was performed with the nonparametric Spearman's test (Sigma Stat. V3.5, SYSTAT, Chicago, IL, USA).

\section{Results}

\section{Clinical details: Patients}

The main clinical parameters from healthy ovulatory women and from patients with PCOS are summarized in Table 1. No differences were found between both groups for age, BMI, and the total dose of rFSH received by each patient. Small follicles were more numerous in PCOS ovaries but this difference was not significant.

\section{BMPs and BMP receptor gene expression in human GCs from normal cycling women}

BMP2, BMP4, BMP5, BMP6, BMP7, and BMP8A mRNA expressions were detected in GCs using PCR techniques (Fig. 1). No signal was found for GDF9 and BMP15 (data not shown). These results were confirmed for BMP4, BMP6, and BMP7 by immunohistochemistry (Fig. 2). Co-localization of aromatase and BMP7 confirmed that BMP7 was actually synthesized by human GCs (Fig. 2).

The activin receptor-like kinases 2 (ALK2 (ACVR1)), ALK5, BMPR1A, BMPR1B, and BMPR2 receptors mRNA were also detected in GCs (Fig. 1) and the

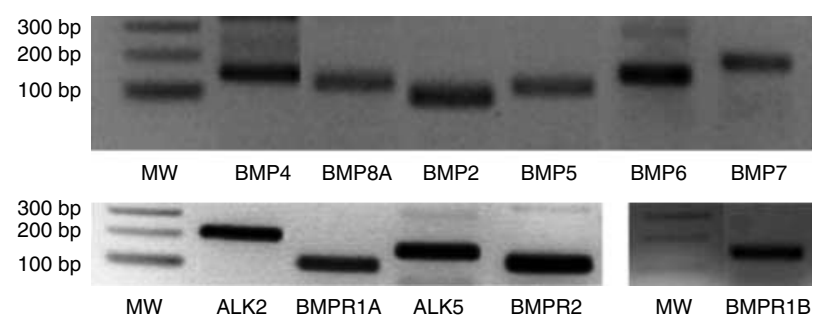

Figure 1 mRNA detection of $B M P 4, B M P 8 A, B M P 2, B M P 5$, BMP6, $B M P 7, A L K 2, B M P R I A, A L K 5, B M P R I I$ and $B M P R I B$ in granulosa cells by RT-PCR. MW, Molecular Weight markers $100 \mathrm{pb}$ DNA Ladder (Promega). 

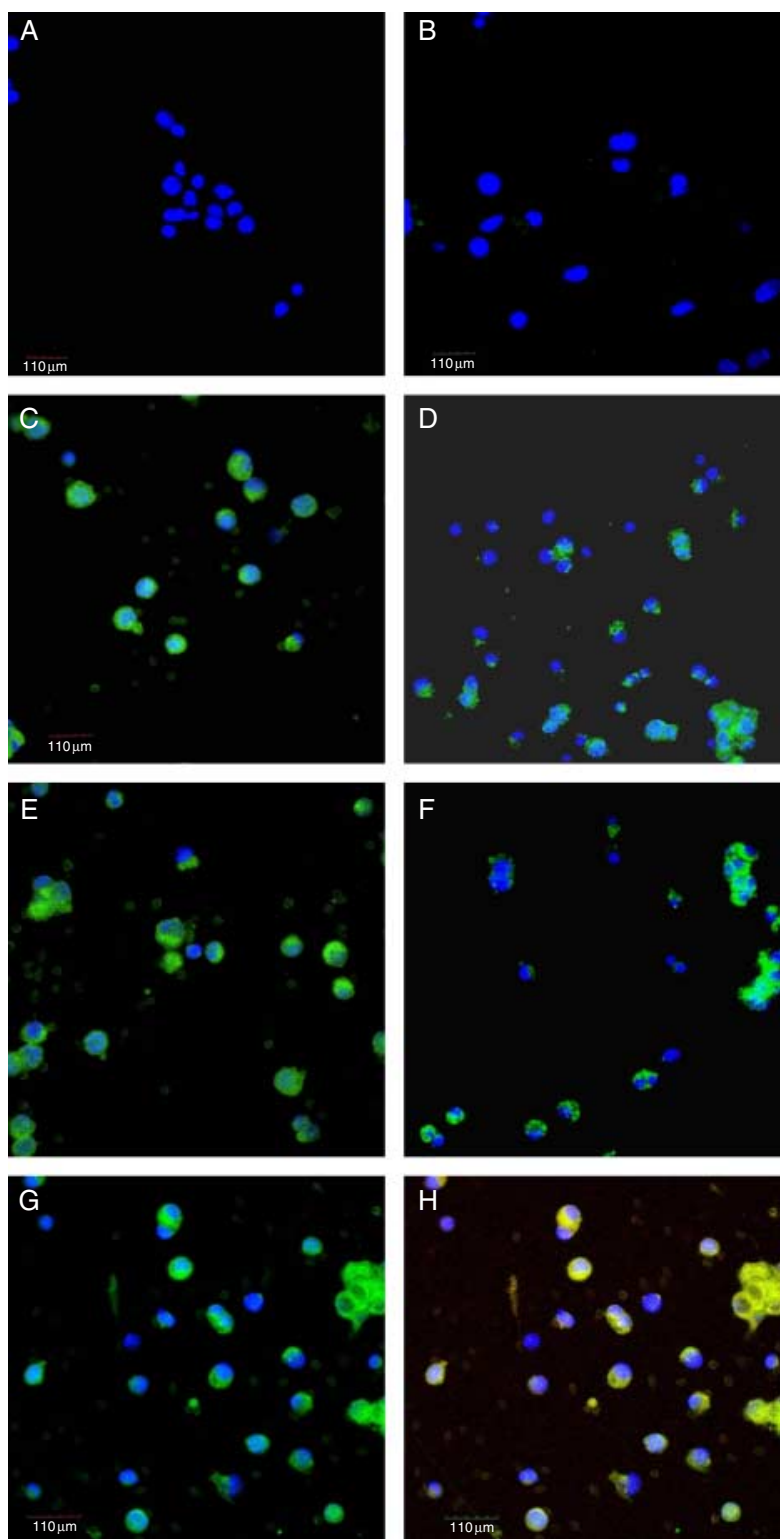

Figure 2 Cells were immunostained with FITC (green) for BMP4 (C), BMP6 (D), BMPRI (E), BMPRII (F), BMP7 (G) and nuclei were counsterstained with DAPI (blue) and examined using confocal microscopy. Cells were immunostained for both aromatase (Texas red) and BMP7 (FITC) (H). The controls for FITC (A) and Texas red (B) staining were realized without primary antibodies. Full colour version of this figure available via http://dx.doi.org/10.1530/EJE-12-0891

presence of proteins BMPR1 and BMPR2 was confirmed by immunohistochemistry (Fig. 2).

\section{Differential expression level of BMP4, BMP6, and BMP7 and their receptors in GCs from normal cycling women}

All BMP expression levels were expressed as the ratio of BMP mRNA to actin mRNA. We observed different expression levels of the different BMPs and their receptors in GCs from normal cycling women. BMP6 was predominantly expressed in comparison with BMP4 and BMP7 $(233 \pm 11$ vs $16 \pm 4$ and $2 \pm 1$ respectively, $P<0.01)$. The BMPR2 receptor was predominantly expressed $(1570 \pm 318)$ compared with the BMPR1A $(460 \pm 110)$ (Fig. 3).

\section{Expression level of BMPs and their receptors in GCs from PCOS women}

BMP6 expression determined by quantitative RT-PCR was higher in GCs from PCOS women compared with healthy women $(P=0.01$; Fig. 4B). BMPR1A expression was also higher in GCs from PCOS women compared with healthy women $(P<0.05$; Fig. 4D). Otherwise, no significant differences were observed between both groups for BMP4, BMP7, BMPR1B, and BMPR2 expression levels (Fig. 4A, C, E and F). The BMP6 mRNA and BMPR1A mRNA levels were strongly and positively correlated in healthy women and PCOS women (Spearman's coefficient $R=0.752, P<0.01$ ). Moreover, no significant difference between healthy women and PCOS women was found in the mRNA expression level for aromatase gene $(7221 \pm 4664$ vs $15546 \pm 2734)$, FSH receptor $(70.7 \pm 81.9$ vs $50.6 \pm 66.5)$, and in the progesterone production by GCs $(164.9 \pm 116.8 \mathrm{pg} / 50000$ cells vs $226.3 \pm 176.3 \mathrm{pg} / 50000$ cells $)$.

\section{Effect of BMPs on basal and FSH-stimulated estrogen production in cultured GCs from healthy ovulatory and PCOS women}

Basal $E_{2}$ production by cultured GCs was threefold higher in PCOS women compared with control women $(108 \pm 22.4$ vs $380 \pm 45.9 \mathrm{pg} / 50000$ cells respectively, $P<0.01$; Fig. 5). Although absolute $E_{2}$ production levels after FSH stimulation were similar in both groups, the FSH-induced $\mathrm{E}_{2}$ increase from baseline was weaker in cells from PCOS compared with healthy women (1.5- vs 3-fold increase respectively; Fig. 5). In cultured cells obtained from normally cycling women, BMP6 and BMP7 but not BMP4 decreased basal $\mathrm{E}_{2}$ production by GCs from healthy women whereas BMPs did not affect basal $E_{2}$ production in PCOS women (Fig. 6A). FSHstimulated $\mathrm{E}_{2}$ production by GCs from control ovary was not affected by BMP, whereas in PCOS ovary a dramatic decrease in $\mathrm{FSH}$-stimulated $\mathrm{E}_{2}$ production was observed in the presence of BMP4 and BMP6 (Fig. 6B).

\section{Discussion}

This study is the first to explore the expression pattern of the BMP family in human GCs. For this purpose, we screened mRNA expression of physiologically relevant BMPs and their membrane receptors in human GCs from healthy ovulatory women and from anovulatory PCOS women. 


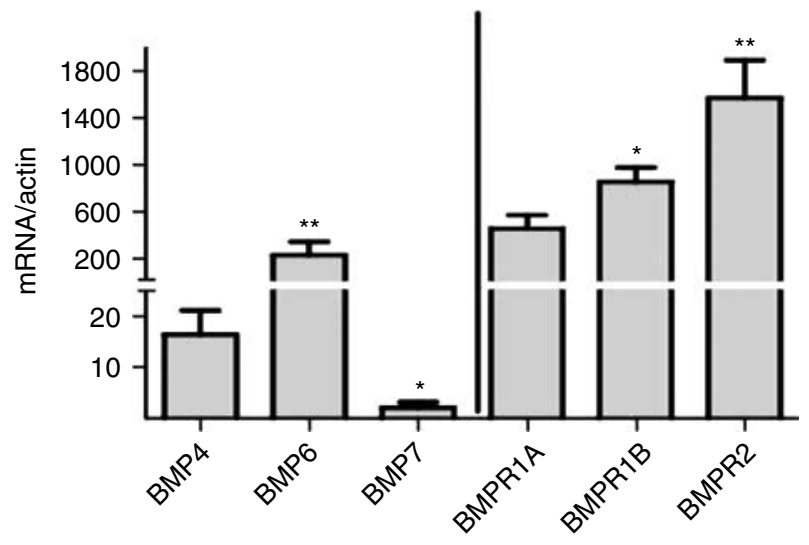

Figure 3 Expression levels of BMPs and their receptors in granulosa cells from women. mRNA expression is quantified with actin as housekeeping gene. Data expressed as the ratio of BMP mRNA to actin mRNA are the mean \pm S.E.M. of six healthy patients. BMP values are compared with BMP4 value and BMP receptors values are compared with BMPR1A. ${ }^{*} P<0.05$ and ${ }^{* *} P<0.01$.

BMPs are the largest subfamily from the TGF $\beta$ superfamily. BMPs were initially identified in bone and cartilage $(18,19,20)$ and thereafter in other tissues including the ovary $(12,21)$. These proteins were shown to regulate several key biological processes in the ovary including cell proliferation, differentiation, apoptosis, and steroidogenesis. Alterations in the BMPs system may be involved in human folliculogenesis disorders such as PCOS that represents the more prevalent endocrine disturbance in women of reproductive age.

We describe for the first time the expression pattern of the BMP in human granulosa-luteinized cells using a RT-PCR approach. We demonstrate that BMP2, BMP4, BMP5, BMP6, BMP7, and BMP8A and their BMPR1A, BMPR1B, and BMPR2 receptors are expressed in ovarian GCs from healthy ovulatory women.

Several of our data may be highlighted: first, BMP4 and BMP7 are expressed by human GCs, in contrast to rodents that exclusively express these proteins in theca cells (21). BMP7 synthesis by GCs was confirmed by immunohistochemistry experiments showing the co-localization of BMP7 and aromatase in GCs (22). Such results illustrate the species specificity of the expression pattern of BMP proteins. We were not able to identify any expression of GDF9 and BMP15 in GCs by RT-PCR. Our data do not confirm previous reports showing an expression of GDF9 in human GCs by an approach using nonspecific immunohistochemistry techniques (23). However, these discrepancies may be explained by the effect of the stimulation protocol used.

The study was also designed to investigate the influence of PCOS on the BMP expression. BMP6 and BMPR1A expression levels were higher in GCs from PCOS compared with normal healthy women. The difference in the number of small follicles in PCOS compared with ovary from healthy women may not fully explain BMP6 and BMPR1A overexpression as a progesterone production of similar magnitude by GCs from PCOS and control follicles suggests the same degree of luteinization between both groups.

Our study is the first to report an overexpression of BMPs in PCOS. This result was independent of the IVF stimulation protocols as the same protocol was used in the two groups. There is evidence that PCOS involves a primary ovarian dysfunction (2) characterized by a twoto threefold increase in follicle number together with an arrest of growing follicles at the $2-5 \mathrm{~mm}$ stage (3), thus explaining the impairment of dominant follicle selection, a hallmark of PCOS pathogenesis. The mechanism of such follicular arrest in PCOS is not fully explained. Studies of the influence of growth factors such as insulin-like growth factor 1 (24), TGF $\beta$, and antiMüllerian hormone (AMH) (25) on the follicle growth disturbance in PCOS were realized. Moreover, early appearance of LH receptor in GCs may drive the premature luteinization of GCs observed in PCOS (26).

Our data suggest that the BMP system may be a new protagonist involved in the etiology of the PCOS. BMP6 overproduction by GCs from PCOS ovary may be involved in the antral follicle accumulation and the anovulatory pattern observed in PCOS. In rodents, BMP6 inhibits FSH action on GCs by suppressing adenylate cyclase activity and by reducing progesterone production (14), which is essential for ovulation $(27,28,29)$. The drop in BMP6 expression in GCs may be permissive at the time of dominant follicle
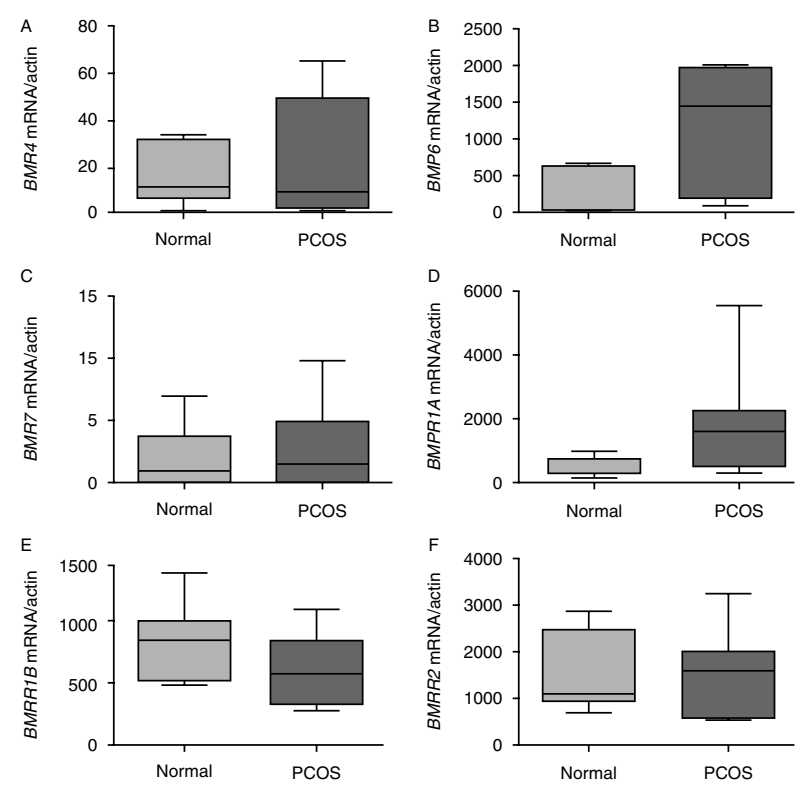

Figure 4 Box-and-whisker plots showing the BMP4 (A), BMP6 (B), $B M P 7(\mathrm{C}), B M P R 1 A(\mathrm{D}), B M P R 1 B(\mathrm{E})$, and BMPR2 (F) mRNA levels (ratio of BMP mRNA to actin mRNA) in granulosa cells from eight PCOS patients and granulosa cells from six healthy patients. Horizontal small bars represent the 10th-90th percentile range and the boxes indicate the 25th-75th percentile range. The horizontal line in each box corresponds to the median. ${ }^{\star} P<0.05$. 


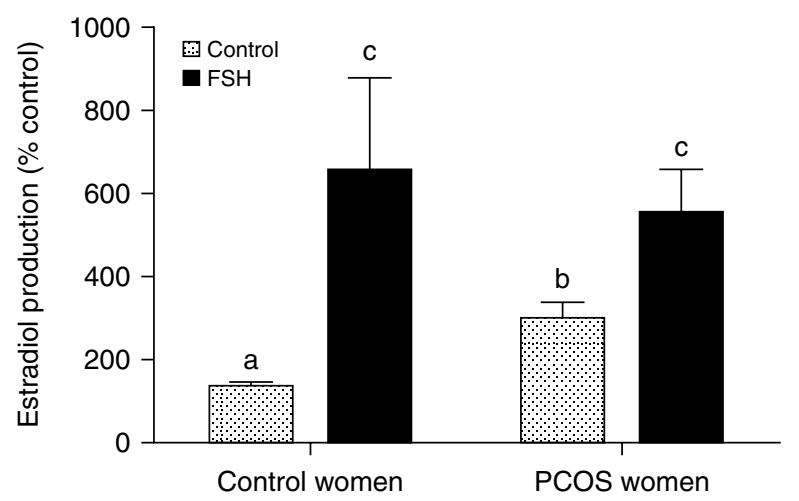

Figure 5 Estrogen production by granulosa cells in six healthy women and eight PCOS women. After $72 \mathrm{~h}$ of culture, granulosa cells were cultured with $10^{-7} \mathrm{M}$ androstenedione and in the presence or absence of $500 \mathrm{mUI} / \mathrm{ml} \mathrm{FSH}$. Results are expressed as mean of ratio of the control value $(\mathrm{a}, \mathrm{b}$ and $\mathrm{c}$ represent a significant difference $(P<0.05))$.

selection, and in PCOS women, BMP6 overexpression may impair the process of selection. Indeed, in rat GC, BMP6 was shown to inhibit FSH-dependent gene expression of LH receptors (14). Based on these findings, we hypothesized that the early appearance of $\mathrm{LH}$ receptor in preantral follicles of PCOS women (24) should be FSH-independent and therefore a BMP6independent event. In opposition to rodent models, BMP6 increases $E_{2}$, androstenedione, and inhibin production in sheep (30). Taken together, these data suggest that an increase in BMP6 expression may explain some features related to anovulation and the arrest of dominant follicle selection observed in PCOS women. An in vitro study by Shi et al. (15) found that FSH receptor, inhibin, activin subunits, and AMH were overexpressed by human GCs cultured in the presence of BMP6. In contrast with these results, we observed in this study no difference in FSH receptor expression between normal and PCOS GCs, which overexpressed BMP6. Other authors found that PCOS GCs originating from subsets of small and large follicles overexpressed FSH receptors in comparison with control cells, a finding of which significance is clouded by the larger FSH dose in the control group which may induce downregulation of FSH receptor (31). The difference observed in these studies may be explained by the stimulation protocol used.

BMP2, BMP4, and AMH bind BMPR1A with different degrees of affinity, which results in triggering the intracellular phosphorylation of Smad 1/5/8 and thus induces a signaling pathway responsible for BMP effects. BMPR1A mediates AMH effect on Smad 1 activation and P450 side-chain cleavage enzyme in Sertoli cell line (SMAT-1) (32). BMP4 modulates FSH signaling in a way that inhibits basal and FSH-stimulated progesterone synthesis in the sheep (33). The enhanced expression of BMPR1A in PCOS GCs may contribute to amplify the effect of BMP4 and AMH in GCs. The increased expression of BMP 6 and BMPR 1 A observed in this study may act synergistically in the pathogenesis of anovulation in PCOS women, as suggested by the positive correlation observed between BMP6 and BMPR1A overexpression in PCOS GCs.

We also performed the first functional studies based on the effect of BMPs on steroidogenesis in human cultured GC. In contrast with GCs from normal cycling women, in PCOS GCs, BMP4 or BMP6 induced a dramatic decrease in FSH-stimulated estrogen production while estrogen basal production was not affected. The overproduction of BMP 6 by PCOS GCs may not explain such an inhibitory effect, as BMP4 and BMP7 also exerted such an inhibitory effects despite lack of overexpression of these proteins in PCOS GCs.

These results suggest that BMP6 overexpression in PCOS GCs may exert an inhibitory effect on FSH-stimulated $\mathrm{E}_{2}$ production and so may induce some degree of resistance to FSH in PCOS women (34). This contrasts with the absence of such an effect in
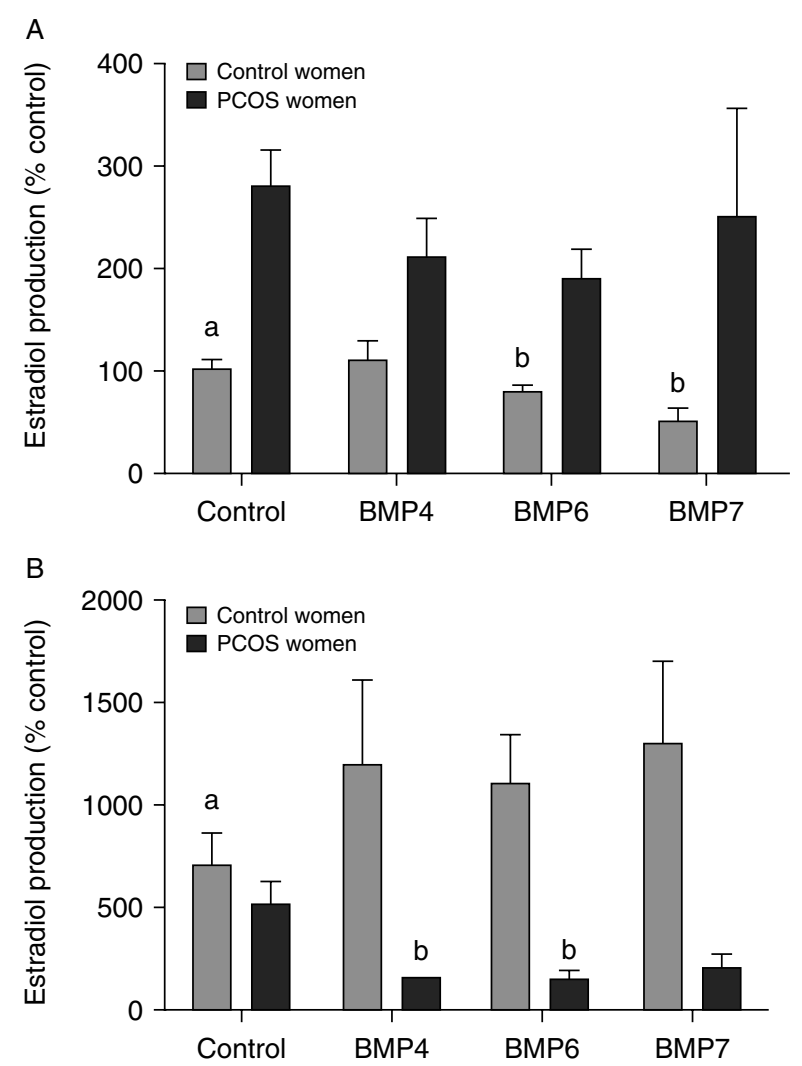

Figure 6 Effect of BMP on (A) basal and (B) stimulated estrogen production in cultured granulosa cells in six healthy and eight PCOS women. After 72-h culture, granulosa cells were cultured with $10^{-7} \mathrm{M}$ androstenedione, in the presence or absence of $500 \mathrm{mUl} / \mathrm{ml} \mathrm{FSH}$ and in the presence or absence of $50 \mathrm{ng} / \mathrm{ml} \mathrm{BMP} 4$, BMP6, or BMP7. Results are expressed as a ratio of the control value without $\mathrm{BMP}$ in healthy granulosa cells ( $\mathrm{a}$ and $\mathrm{b}$ represent a significant difference $(P<0.05))$. 
GCs from normal cycling women and in rodent studies $(11,14)$. This inhibitory effect of BMP6 could affect aromatase activity as the levels of $\mathrm{FSH}$ receptor and aromatase mRNA were not modified in PCOS cells.

In the presence of FSH and BMP in cell culture medium, $\mathrm{E}_{2}$ production level from PCOS GCs is similar to the unstimulated basal $\mathrm{E}_{2}$ production level, highlighting the inhibitory effects of BMP on FSH-dependent steroidogenesis. In our study conditions, the basal $E_{2}$ level is threefold higher in PCOS compared with normal GCs as described previously by Mason et al. (35), suggesting that BMP effects are mediated mainly by FSH and that enhanced $\mathrm{E}_{2}$ basal production in PCOS GCs is driven by another trigger independently from BMP.

In conclusion, the present data raise the question on the involvement of the BMP system in the pathogenesis of PCOS. The different expression patterns of BMP proteins observed in PCOS compared with normal ovaries suggest that gonadotropin stimulation of PCOS ovaries did not fully reverse the folliculogenesis disturbance present in PCOS, i.e. alterations of expression patterns of BMP proteins that may be involved in follicle development disruption. Further studies are needed to explore the mechanism involved in BMP overexpression in PCOS ovary and to study the signaling pathways involved in the BMP actions on human GCs.

\section{Supplementary data}

This is linked to the online version of the paper at http://dx.doi.org/10. 1530/EJE-12-0891.

\section{Declaration of interest}

The authors declare that there is no conflict of interest that could be perceived as prejudicing the impartiality of the research reported.

\section{Funding}

This study was supported by PHRC 2009 (Hospital Clinical Research Program), number 0605, France.

\section{References}

1 Franks S. Polycystic ovary syndrome. New England Journal of Medicine 1995333 853-861. (doi:10.1056/NEJM1995092 83331307)

2 Hughesdon PE. Morphology and morphogenesis of the SteinLeventhal ovary and of so-called "hyperthecosis". Obstetrical \& Gynecological Survey 198237 59-77. (doi:10.1097/00006254198202000-00001)

3 Webber LJ, Stubbs S, Stark J, Trew GH, Margara R, Hardy K \& Franks S. Formation and early development of follicles in thepolycystic ovary. Lancet 2003362 1017-1021. (doi:10.1016/ S0140-6736(03)14410-8)

4 Maciel GA, Baracat EC, Benda JA, Markham SM, Hensinger K, Chang RJ \& Erickson GF. Stockpiling of transitional and classic primary follicles in ovaries of women with polycystic ovary syndrome. Journal of Clinical Endocrinology and Metabolism 2004 89 5321-5327. (doi:10.1210/jc.2004-0643)
5 Shimasaki S, Moore RK, Otsuka F \& Erickson GF. The bone morphogenetic protein system in mammalian reproduction. Endocrine Reviews 200425 72-101. (doi:10.1210/er.2003-0007)

6 Aaltonen J, Laitinen MP, Vuojolainen K, Jaatinen R, HorelliKuitunen N, Seppä L, Louhio H, Tuuri T, Sjöberg J, Bützow R et al. Human growth differentiation factor 9 (GDF-9) and its novel homolog GDF-9B are expressed in oocytes during early folliculogenesis. Journal of Clinical Endocrinology and Metabolism 199984 2744-2750. (doi:10.1210/jc.84.8.2744)

7 Bodensteiner KJ, Clay CM, Moeller CL \& Sawyer HR. Molecular cloning of the ovine growth/differentiation factor-9 gene and expression of growth/differentiation factor-9 in ovine and bovine ovaries. Biology of Reproduction 199960 381-386. (doi:10.1095/ biolreprod60.2.381)

8 Bodensteiner KJ, McNatty KP, Clay CM, Moeller CL \& Sawyer HR. Expression of growth and differentiation factor-9 in the ovaries of fetal sheep homozygous or heterozygous for the inverdale prolificacy gene $(\mathrm{FecX}(\mathrm{I}))$. Biology of Reproduction $2000 \mathbf{6 2}$ 1479-1485. (doi:10.1095/biolreprod62.6.1479)

9 Galloway SM, McNatty KP, Cambridge LM, Laitinen MP, Juengel JL, Jokiranta TS, McLaren RJ, Luiro K, Dodds KG, Montgomery GW et al. Mutations in an oocyte-derived growth factor gene (BMP15) cause increased ovulation rate and infertility in a dosage-sensitive manner. Nature Genetics 200025 279-283. (doi:10.1038/ 77033)

10 Teixeira Filho FL, Baracat EC, Lee TH, Suh CS, Matsui M, Chang RJ, Shimasaki S \& Erickson GF. Aberrant expression of growth differentiation factor-9 in oocytes of women with polycystic ovary syndrome. Journal of Clinical Endocrinology and Metabolism 200287 1337-1344. (doi:10.1210/jc.87.3.1337)

11 Lee WS, Otsuka F, Moore RK \& Shimasaki S. Effect of bone morphogenetic protein-7 on folliculogenesis and ovulation in the rat. Biology of Reproduction 200165 994-999. (doi:10.1095/ biolreprod65.4.994)

12 Erickson GF \& Shimasaki S. The spatiotemporal expression pattern of the bone morphogenetic protein family in rat ovary cell types during the estrous cycle. Reproductive Biology and Endocrinology 20031 9. (doi:10.1186/1477-7827-1-9)

13 Durlinger AL, Gruijters MJ, Kramer P, Karels B, Kumar TR, Matzuk MM, Rose UM, de Jong FH, Uilenbroek JT, Grootegoed JA et al. Anti-Müllerian hormone attenuates the effects of FSH on follicle development in the mouse ovary. Endocrinology 2001142 4891-4899. (doi:10.1210/en.142.11.4891)

14 Otsuka F, Moore RK \& Shimasaki S. Biological function and cellular mechanism of bone morphogenetic protein- 6 in the ovary. Journal of Biological Chemistry 2001276 32889-32895. (doi:10.1074/jbc.M103212200)

15 Shi J, Yoshino O, Osuga Y, Koga K, Hirota Y, Hirata T, Yano T, Nishii O \& Taketani Y. Bone morphogenetic protein-6 stimulates gene expression of follicle-stimulating hormone receptor, inhibin/activin $\beta$ subunits, and anti-Müllerian hormone in human granulosa cells. Fertility and Sterility 200992 1794-1798. (doi:10.1016/j.fertnstert.2009.05.004)

16 Shi J, Yoshino O, Osuga Y, Nishii O, Yano T \& Taketani Y. Bone morphogenetic protein 7 (BMP-7) increases the expression of follicle-stimulating hormone (FSH) receptor in human granulosa cells. Fertility and Sterility 201093 1273-1279. (doi:10.1016/j. fertnstert.2008.11.014)

17 Miyoshi T, Otsuka F, Inagaki K, Otani H, Takeda M, Suzuki J, Goto J, Ogura T \& Makino H. Differential regulation of steroidogenesis by bone morphogenetic proteins in granulosa cells: involvement of extracellularly regulated kinase signaling and oocyte actions in follicle-stimulating hormone-induced estrogen production. Endocrinology $2007 \mathbf{1 4 8} 337-345$. (doi:10.1210/en. 2006-0966)

18 Urist MR. Bone: formation by autoinduction. Science 1965150 893-899. (doi:10.1126/science.150.3698.893)

19 Urist MR, Mikulski A \& Lietze A. Solubilized and insolubilized bone morphogenetic protein. PNAS $1979 \quad \mathbf{7 6} \quad 1828-1832$. (doi:10.1073/pnas.76.4.1828) 
20 Urist MR \& Strates BS. Bone morphogenetic protein. Journal of Dental Research 197150 1392-1406. (doi:10.1177/00220 345710500060601)

21 Shimasaki S, Zachow RJ, Li D, Kim H, Iemura S, Ueno N, Sampath K, Chang RJ \& Erickson GF. A functional bone morphogenetic protein system in the ovary. PNAS 199996 7282-7287. (doi:10.1073/pnas.96.13.7282)

22 Hillier SG, van den Boogaard AJ, Reichert LE Jr \& van Hall EV. In-vitro studies on the aromatase activity of granulosa cells obtained from developing follicles in the normal human ovary [proceedings]. Journal of Endocrinology 197983 45P-46P.

23 Zhao SY, Qiao J, Chen YJ, Liu P, Li J \& Yan J. Expression of growth differentiation factor-9 and bone morphogenetic protein-15 in oocytes and cumulus granulosa cells of patients with polycystic ovary syndrome. Fertility and Sterility 201094 261-267. (doi:10.1016/j.fertnstert.2009.03.014)

24 Mazerbourg S, Bondy CA, Zhou J \& Monget P. The insulin-like growth factor system: a key determinant role in the growth and selection of ovarian follicles? A comparative species study. Reproduction in Domestic Animals 200338 247-258. (doi:10.1046/j.1439-0531.2003.00440.x)

25 Josso N, di Clemente N \& Gouédard L. Anti-Müllerian hormone and its receptors. Molecular and Cellular Endocrinology 2001179 25-32. (doi:10.1016/S0303-7207(01)00467-1)

26 Jakimiuk AJ, Weitsman SR, Navab A \& Magoffin DA. Luteinizing hormone receptor, steroidogenesis acute regulatory protein, and steroidogenic enzyme messenger ribonucleic acids are overexpressed in thecal and granulosa cells from polycystic ovaries. Journal of Clinical Endocrinology and Metabolism 200186 1318-1323. (doi:10.1210/jc.86.3.1318)

27 Mori T, Suzuki A, Nishimura T \& Kambegawa A. Inhibition of ovulation in immature rats by anti-progesterone antiserum. Journal of Endocrinology 197773 185-186. (doi:10.1677/joe.0. 0730185)

28 Rao IM \& Mahesh VB. Role of progesterone in the modulation of the preovulatory surge of gonadotropins and ovulation in the pregnant mare's serum gonadotropin-primed immature rat and the adult rat. Biology of Reproduction $1986 \quad 35 \quad 1154-1161$. (doi:10.1095/biolreprod35.5.1154)

29 Yoshimura Y \& Wallach EE. Studies of the mechanism(s) of mammalian ovulation. Fertility and Sterility 198747 22-34.

30 Campbell BK, Kendall NR \& Baird DT. Effect of direct ovarian infusion of bone morphogenetic protein 6 (BMP6) on ovarian function in sheep. Biology of Reproduction 200981 1016-1023. (doi:10.1095/biolreprod.109.076653)

31 Catteau-Jonard S, Jamin SP, Leclerc A, Gonzalès J, Dewailly D \& di Clemente N. Anti-Müllerian hormone, its receptor, FSH receptor, and androgen receptor genes are overexpressed by granulosa cells from stimulated follicles in women with polycystic ovary syndrome. Journal of Clinical Endocrinology and Metabolism 2008 93 4456-4461. (doi:10.1210/jc.2008-1231)

32 Belville C, Jamin SP, Picard JY, Josso N \& di Clemente N. Role of type I receptors for anti-Müllerian hormone in the SMAT-1 Sertoli cell line. Oncogene 200524 4984-4992. (doi:10.1038/sj.onc.1208686)

33 Mulsant P, Lecerf F, Fabre S, Schibler L, Monget P, Lanneluc I, Pisselet C, Riquet J, Monniaux D, Callebaut I et al. Mutation in bone morphogenetic protein receptor-IB is associated with increased ovulation rate in Booroola Merino ewes. PNAS 200198 5104-5109. (doi:10.1073/pnas.091577598)

34 Magoffin DA. Ovarian enzyme activities in women with polycystic ovary syndrome. Fertility and Sterility 200686 (Suppl 1) S9-S11. (doi:10.1016/j.fertnstert.2006.03.015)

35 Mason HD, Margara R, Winston RM, Beard RW, Reed MJ \& Franks S. Inhibition of oestradiol production by epidermal growth factor in human granulosa cells of normal and polycystic ovaries. Clinical Endocrinology 199033 511-517. (doi:10.1111/j.13652265.1990.tb03888.x)

Received 10 October 2012

Revised version received 7 December 2012

Accepted 14 December 2012 